\title{
ORBÁN SÁNDOR
}

\section{A 70 ÉVES VARGA JÁNOS TANÁR ÚR KÖSZÖNTÉSE}

\author{
Eszterházy Károly Egyetem Biológiai Intézet, Növénytani Tanszék \\ E-mail:orban82@gmail.com
}

Mottó: „A pedagógus a nemzet napszámosa."

(Gárdonyi Géza)

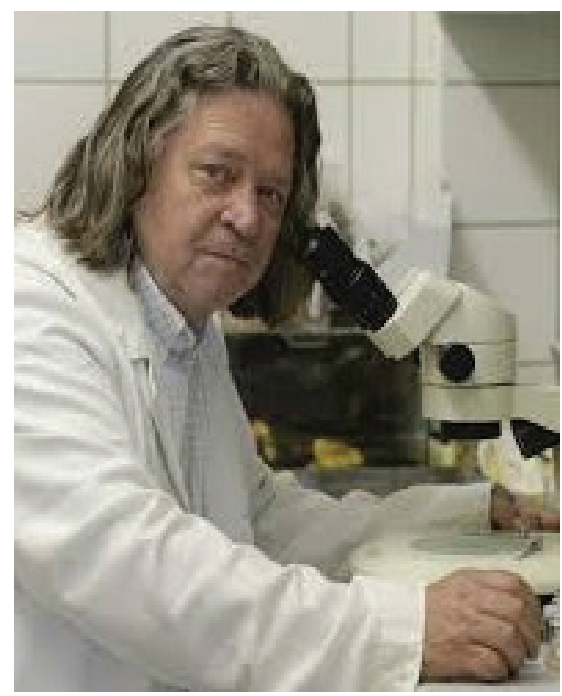

Varga János 1949. november 17-én született a Pest megyei Erdőkertesen, általános iskoláit helyben végezte. Középiskolai tanulmányait a közeli városban Gödöllőn (Máriabesnyőn), a Török Ignác Gimnáziumban 1968-ban fejezte be. Ezt követően egy évig különböző munkakörökben dolgozott (építőiparban, közigazgatásban stb.). 1969-ben nyert felvételt az Egri Tanárképző Főiskola biológia-mezőgazdaság szakára. A főiskolai tanulmányait 1973-ban fejezte be, és tanári állást vállalt a Galgahévízi Általános Iskolában, ahol egy fél évig tanított.

1974-ben pályázat útján került ismét az egri főiskolára, főigazgatói titkári kinevezést kap, mely funkciót 1981-ig látta el. Mint főigazgatói titkárnak számos, az egész intézményre kiterjedő adminisztratív és koordináló feladata volt (intézményi ünnepségek, rendezvények, hazai és nemzetközi konferenciák szervezése), jó szervezőkészségének kialakításában ebben a beosztásban végzett munkája is szerepet játszott. Közben levelező tagozaton, Szegeden JATE biológia szakán 1978-ban középiskolai biológia tanári diplomát szerez. 
Oktatói tevékenysége. 1981-tôl az Állattani Tanszék teljes állású oktatójának nevezik ki (tanársegédi, majd adjunktusi fokozatban). Abban az időben „divat volt", hogy a fiatal oktatóknak minden tantárgyat oktatniuk kellett - előadást és gyakorlatot is -, így végigtanított minden állattani tárgyat, állatszervezettant, állatrendszertant, állatföldrajzot, állatökológiát, állatélettant, származástant, iskolaegészségtant és szakmódszertant is. Szívesen látogatta volt tanárainak, Dr. Vajon Imre, Hoblyák János és kollégáinak, Dr. Kiss Ottó, Dr. Bartos László és Nagy István színvonalas gyakorlatait és elméleti előadásait, az itt látott és hallott ismeretek jelentős mértékben segítették és alakították a további oktatói és kutatói tevékenységét.

Az általa tanított tantárgyakhoz tankönyvek, jegyzetek készítésébe is bekapcsolódott kezdetben társszerzőként, majd önállóan írt oktatási anyagokat. 1989-ben jelent meg a Tankönyv Kiadó gondozásában első, Dr. Sey Ottóval társszerzőként írt tankönyve Származástan címmel.

1990-ben főiskolai docensi kinevezésben részesül, és továbbra is az Állattani Tanszék keretein belül végzi munkáját. 1991-től elkezdődik a tanárképző főiskolák felzárkóztatása a tudományegyetemek mellé, mely a tantervek és tantárgyak egyeztetését, illetve azok színvonalban egymáshoz közelítését igényelte. Ebben a munkafolyamatban az állattani tárgyaknak és tanterveknek az egyetemekkel való koordinálására kapott megbízást. Ezeknek a munkafolyamatoknak az eredményeként születtek meg aztán a hazai egyetemekkel közös (egységes) tantervek és oktatott tantárgyak. Az újonnan bevezetett tantárgyak egyike a Szünbiológia volt, amit Dr. Kárász Imrével együtt oktatott. Közös munkájuk eredményeként 1990-ben jelent meg Szünbiológia Terepgyakorlat címú munkafüzetük, ami a megjelenésének időszakában szakmailag és metodikailag is újszerü és modern munkának számított.

Közben a hagyományosan oktatott tárgyak klasszikus tananyagai is modernizálódtak, ezért ezekhez is modernebb, naprakészebb szemléletú jegyzetanyagokat, segédanyagokat kellett készíteni. 1991-ben Állatrendszertan II. és 1995-ben az Állatrendszertan I. címen jelentek meg gyakorlati jegyzetei. 1995ben készült el az Állatföldrajz címú jegyzete, melyet Dr. Rácz István társszerzővel állított össze. Az állatföldrajz jegyzet hiánypótló munkának számított, négy suplement kiadást élt meg, és még napjainkban is használják a tárgy oktatása során.

1993-ban a Biológiai Intézetnek át kellett költöznie az akkor átadott, újonnan kialakított $D$ épületbe, ahol előre megtervezett laborok, előadók, szemináriumi termek és irodák várták az oktatói, kutatói, laboráns és adminisztrációs állományt. Mivel a költözködés a nyári időszakra esett, az egész folyamatot Varga tanár úr 1-2 laboráns és szállítómunkás segítségével vezényelte le, de szeptemberben már indulhatott az órarend szerinti oktatás az új tanszéki körülmények között.

A következő kihívást az oktatási reformok jelentették számára. A 2000-es évek elején a bolognai rendszerű oktatásra való átállás vette kezdetét. A bevezetésre kerülő 6 féléves alapképzés és a ráépülő 4 féléves mesterképzés teljesen 
más tantervi struktúrát igényelt. További és újabb egyeztetésekre volt szükség az egyetemekkel, hiszen az akkreditáció megkövetelte, hogy az alapképzési szakasz alapjaiban véve megegyezzen, a mesterképzésben pedig jelenjen meg a specializáció, vagyis a tanári pályára való felkészítés. A bolognai rendszerü oktatás tantervi hálóinak egységesítésében, majd a tantárgyleírások elkészítésében is aktívan részt vett. A bolognai rendszerü képzés miatt a tanárképzés háttérbe szorult, ezért 2010-től megjelent a felsőoktatásban az osztatlan kétszakos tanárképzés, s ebben már helyet kapott, nagyobb (hangsúlyozottabb) jelentőségűvé vált ismételten a biológia szakos tanárképzés is.

Az új képzési rendszerekre való átállás során új (részben ez idáig nem oktatott) tantárgyak bevezetésére is sor került. Varga tanár úr bekapcsolódott a Növénytani és az Állattani Tanszékkel közösen gondozott Ökológia I., II., III. tárgyak oktatásába. 2002-ben látott napvilágot az Állatrendszertani munkafüzet (Elméleti áttekintés és gyakorlatok) című jegyzete (amely a hazai egyetemek közül több helyen is szerepel az ajánlott irodalomjegyzékben). Szintén 2002ben jelent meg a Bevezetés az őslénytanba és a paleoökölógiába című jegyzet, melynek összeállításában Dr. Füköh Levente és Dávid Árpád társzerzőjeként vett rész.

Az Evolúcióbiológia és populációgenetika tantárgyhoz 2006-ban jelent meg Evolúció című jegyzete. A Veszélyes állatok. Parazita állatok, az ember parazitái. Állati eredetü fertőzések (zoonózisok) megbetegedések című tantárgyhoz 2010-ben készített jegyzetet. Zoológiai élőhely-és élőlényismeret tantárgy oktatását elősegítő munkája (jegyzete) 2011-ben került kiadásra. Ennek az elméleti tantárgynak a gyakorlati munkafüzetét még ebben az évben készíti el Horotán Katalinnal. 2016-ban az Élettelen környezeti tényezők állapota és változása címen megjelent elektronikus jegyzete alapvetően az Ökológia III. tárgy feldolgozásához és napjaink környezeti problémáinak megértéséhez nyújt támpontot, nemcsak a biológia szakos hallgatók számára. A jegyzet társszerzője Horotán Katalin.

Terepgyakorlatok: a hallgatók részére a kedvelt(ebb) oktatási feladatok közé tartoznak, amelyek megszervezésére és kivitelezésére mindig alaposan felkészült. Különböző oktatási segédanyagokat és terepi jegyzőkönyveket készített a terepi foglalkozásokhoz is. 2015-ben jelent meg a Terepi gyüjtési technikák, rovarok gyújtése és preparálása címü munkája, a kötet a Nemzeti Kulturális Alap támogatásával készült (társszerző: Földessy Mariann, Horotán Katalin).

Az általa írt jegyzetek közös jellemzője, hogy nagyon sok idézettel támasztja alá a szövegközi környezetben megfogalmazottakat. Az egyes fejezetekhez kapcsolódó tudományos, szakmai, filozófiai, illetve hazai és külföldi szépirodalmakból ismert neves íróktól és költőktől vett idézetek nemcsak a témakör tanulásához és megértéséhez nyújtanak hangulatilag is motiváló alapot, de a tanárképzéshez és a tanári pályához is nélkülözhetetlen általános müveltség elmélyítését is szolgálják. Jelenleg a jegyzetírás mellett az online oktatás segédanyagainak összeállításában vesz részt.

Oktató munkája mellett folyamatosan irányította a hallgatók szakdolgozati tevékenységét. Az eltelt évtizedek alatt 500 hallgató készítette nála a diplo- 
mamunkáját. A legjobb szakdolgozó hallgatókat a diákköri munkába (TDK) is bevonta, 15 hallgatója szerzett díjat OTDK-konferenciákon az elmúlt évtizedekben.

Tudományos tevékenysége. Az univ. doktori címet már 1982-ben megszerzi. "A ponty (Cyprinus carpio) mesonephrosa fény- és scanning elektronmikroszkópos feldolgozása" című disszertációját 1982-ben Szegeden védte meg. Az Állattani Tanszék kutatási profiljának változása miatt nem folytatja tovább hisztológiai vizsgálatait. 1986 táján új kutatásokba kezdett. Érdeklődése a mohákban élő állategyüttesek (briofauna) kutatására irányult. Kezdetben a különböző életstratégiájú mohafajok állategyütteseit vizsgálja. Később áttér a mohák és a bennük előforduló állati szervezeteknek a környezetszennyezés - kiemelten a nehézfémszennyezés hatására - kimutatható összefüggések elemzésére. Közben 1996-ban tagja lesz egy briológiai expedíciónak Réunion szigetén, melynek kutatási célja a trópusi sziget mohafajainak cönológiai feldolgozása volt. Az itt gyűjtött állatfajokat a Természettudományi Múzeumnak adta át.

A környezetszennyezés és briofauna kapcsolatának vizsgálatai a 90-es évek végén és a 2000-es évek elején folynak nagy intenzitással. A nehézfémszennyezés és a mohákban élő állatok táplálkozásbiológiája, és az ehhez kapcsolódó biomagnifikációs vizsgálatok kerültek kutatásainak előterébe. Az ez irányú vizsgálatainak eredményei nemzetközi szinten is ismertté tették a briofauna kutatóinak körében. A kutatásait végezve döntötte el, hogy ebből a témából készíti el disszertációját, és megszerzi a kandidátusi fokozatot, ami kortársaitól eltérően kimaradt az életéből. A „Dynamics of migration and accumulation of Lead in mosses communities of invertebrates in the National park "Bükk" (the Hungarian Republic)" címú disszetációját Ukrajnában, a Kijevi Nemzeti Egyetemen (Kyiv Taras Shevchenko University National) védi meg, és 2011-ben a Biológia, Ökológiai tudományok kandidátusa lesz. Diplomáját a Magyar Akkreditációs Bizottság javaslatára Gödöllőn, a Szent István Egyetemen 2013-ban honosíttatta át PhD-fokozattá. Ezt követően is főiskolai docensi beosztásában dolgozik, és a korábbiakhoz hasonlóan végzi oktatási és kutatási munkáját.-

Tudományos tevékenységét tükrözik a következőkben felsorolt számszerü adatok: Nemzetközi szakmai konferenciákon való részvétel: 12. Hazai (országos) szakmai konferenciákon való részvétel: 51. Idegen nyelven megjelent publikációk száma: 18. Magyarországon megjelent publikációk száma: 51. Tankönyvek, jegyzetek száma: 25 (gyakorlati foglalkozásokhoz összeállított munkafüzetek száma: 16). Könyvfejezetek száma: 4. Ismeretterjesztő cikkek száma: 9. Lektorálás (hazai és külföldi könyvek, jegyzetek, szakcikkek): 6.

Oktatói tevékenysége mellett igyekezett aktívan részt venni az intézményre háruló egyéb közös feladatok megoldásába is.

Részt vállalt az intézményben szervezett továbbképzésekben. 1989-ben a Főiskolán folyó pedagógus továbbképzés keretében jelentetik meg Dr. Kárász Imrével az Ökológiai és környezetvédelmi terepgyakorlatok címú oktatási segédanyagukat, az intenzív pedagógus továbbképzés biológia szakos hallgatói részére. 
1990-től indult Csíkszeredán a távoktatás a Pro Agricultura Hungariae Alapítvány keretében, amiben az Eszterházy Károly Főiskola is részt vett biológia szakos tanárképzés indításával, melyben az állattani tárgyak oktatásáért felelős tanára volt 2005-ig. Oktatta a hagyományos tantárgyait, előadásokat, gyakorlatokat és terepgyakorlatokat szerevezett az erdélyi hallgatók részére, és irányította néhányuk diplomamunkájának elkészítését is. A képzéshez kapcsolódóan készül el a Hargita megye védett állatai. Gerincesek (Vertebrata) címü oktatási segédanyag, melynek a szerkesztője volt, s melyet Pomjánek Béla társszerzővel állított össze 1997-ben.

Szervezte az intézményben az 1990-es évek elején beindult Országos Posztgraduális Képzést (melynek, intézményi koordinátára is volt). Kidolgozta és irányította az akkori Neveléstudományi Tanszékkel együttműködve az "Egészségfejlesztő és mentálhigiénés pedagógus továbbképzést", mely több éven keresztül érdeklődéssel kísért továbbképzési forma volt.

1993-tól látja el az Acta Academiae Paedagogicae Agriensis folyóirat zoológiai szekciójának, 2005-től a biológiai szekció köteteinek, 2020-tól Acta Universitatis de Carolo Eszterhazy Nominate sectio Biologiae kidvány szerkesztési munkáit, melynek rendszeres és külön kiadású kötetei évente, illetve kétévente jelentek meg.

Bekapcsolódott a "Tájkutatások - Természetvédelem" Tehetséggondozó mühely (2009/2010) munkájába, ahol előadások tartásával és az az állattani irányultságú témát választó hallgatók kutatásának koordinálásával segítette a tehetséggondozó műhely munkáját.

A Biológiai Intézetben 2010-től négy féléves OKJ-s képzésekre is sor került. Ezek közül a Múzeumi preparátor szaknak a programfelelőse volt. A Múzeumi preparátor képzés a Természettudományi Múzeum és a Mátra Múzeum munkatársaival együttműködésben közösen zajlott. A képzés eredményességét igazolja, hogy a végzett hallgatók szinte mindegyike az oklevél megszerzését követően sikeresen helyezkedett el a szakképesítésének megfelelő munkahelyeken. Részt vett továbbá a Gyógy- és füszernövény termesztő és feldolgozó szak képzési programjában. 2013-ban Dr. Pénzesné Kónya Erika által szerkesztett Ökológia jegyzet. Gyógy- és füszernövény termesztő és feldolgozó felsőfokú szakképzésben részt vevő hallgatók számára című elektronikus tananyag társszerzője volt.

A 2010-es években a "föiskola hallgatói tartózkodási terek kialakitására" nyert pályázatot. Ekkor a TTK D épülete is átalakításra került. Az épület 3-4. szintjén, a folyosókon lett elhelyezve a Természettudományi Kiállítás (Látványtár). Az kiállítás megtervezését (koncepcióterv, forgatókönyv) Varga tanár úr végezte, ügyelve arra, hogy megfelelően látványos és didaktikailag is használható legyen a kiállított anyag, amely nemcsak az egyetemi oktatásra, hanem érdeklődő diákok és más, nem szakemberek fogadására is alkalmassá vált. A kiállítás berendezésének fizikai munkálatait (a pincében elhelyezett kiállítási anyag, kitömött állatok, folyadékos preparátumok végleges helyére szállítását) is magára vállalta.

Ismeretterjesztő munkája is említésre méltó, indulása óta bemutatókkal, előadásokkal kapcsolódott be a "Kutatók Éjszakája” rendezvények programja- 
iba. A „Varázstorony" ismertterjesztő előadásait is szívesen vállalta fel állattani témákban. Nyári táborok tematikus foglalkozásaiba (Eger, Erdőtelek, Balaton stb.) mint ötletgazda és megvalósító vett és vesz részt. Több mint 100 ismeretterjesztő előadást tartott, hazai általános és középiskolákban, pedagógus és szakmai továbbképzések keretében, a hazai és külföldi helyszíneken (Ungvár, Erdély stb.) egyaránt.

A hallgatói jogviszonyát is figyelembe véve 50 éve kötődik az intézményhez. Eközben négy alkalommal változott az intézmény neve. Nagy örömet szerzett számára, hogy részese, oktatója lehetett az Eszterházy Károly Egyetem Állattani Tanszékén, egyetemi szinten zajló tanárképzésnek is. Élete jelentős részében beosztott oktató volt, de két alkalommal megbízott tanszékvezetői feladatokat is ellátott, 1991-1992 és 2008-2010 között.

Elismerések, kitüntetések. Munkáját több alkalommal is elismerték. A rendszerváltásig az abban az időszakban hagyományos törzsgárda érmeket kapott a ledolgozott évtizedek után. 1995-ben az Erdélyi Magyar Pedagógiai Társaság elismerő oklevelét kapta meg, majd 2011-ben az EKTF-TTK által alapított Kiss Péter-díjban részesült.

Egy hallgatói jellemzés szerint: „Érdekes egyéniség, de egy biztos, tanárként és emberként sem egy hétköznapi figura. Nem törekszik rá, de nyomot hagy maga után mindenkiben, aki ismeri".

Kedves tanár úr! A volt és jelenlegi tanítványaiddal, munkatársaiddal és kollégáiddal együtt kívánunk Neked további eredményes tanszéki elfoglaltságot és kutatómunkát. Isten éltessen sokáig körünkben! 